\title{
Effect of controlled atmosphere conditions on the quality and internal disorder of early season 'Fuji' apples during storage
}

\author{
Ho Hyun Chun ${ }^{1 *}$, Seok Ho Park ${ }^{2}$, Dong Soo Choi ${ }^{2}$, Seung Ryul Choi ${ }^{2}$, \\ Jin Se Kim², Jin Su Lee ${ }^{3}$ \\ ${ }^{1}$ Advanced Process Technology and Fermentation Research Group, World Institute of Kimchi, Gwangju 61755, Korea \\ ${ }^{2}$ Postharvest Engineering Division, National Academy of Agricultural Science, RDA, Wanju 55365, Korea \\ ${ }^{3}$ Postharvest Research Team, National Institute of Horticultural and Herbal Science, RDA, Wanju 55365, Korea
}

\section{Controlled atmosphere 저장 시스템을 이용한 기체조성 변화가 조생 '후지' 사과의 저장 중 품질 및 내부장해 발생에 미치는 영향}

\author{
천호현 ${ }^{*} \cdot$ 박석호 $^{2} \cdot$ 최동수 ${ }^{2} \cdot$ 최승렬 $^{2} \cdot$ 김진세 $^{2} \cdot$ 이진수 $^{3}$ \\ ${ }^{1}$ 세계김치연구소 신공정발효연구단, ${ }^{2}$ 농촌진흥청 국립농업과학원 수확후관리공학과, \\ 3농촌진흥청 국립원예특작과학원 저장유통연구팀
}

\begin{abstract}
This study was conducted to investigate the change in the quality of early season Fuji apples that were subjected to eight different storage conditions using the developed controlled atmosphere (CA) storage system. Early season Fuji apples grown at Mungyeong, in the South Korea, were harvested in September 2014 for storage studies. Flesh firmness, titratable acidity, total soluble solid content, weight loss, and internal browning disorder were used as quality indicators for the stored apples. Flesh firmness and weight loss were better than that of the control after 70 days of storage. However, there was no significant difference in the titratable acidity or total soluble solid content among the apple samples from eight chambers after storage. The intemal browning disorder of apple samples in $\mathrm{CA}$ chambers occurred when exposed to $1 \% \mathrm{CO}_{2}+2 \% \mathrm{O}_{2}$ and $1 \% \mathrm{CO}_{2}+0.5 \% \mathrm{O}_{2}$, resulting in a higher incidence rate of 2 and $8 \%$ after 70 days of storage than that in the control. In addition, the CA storage conditions at 3, 4 and $5 \% \mathrm{CO}_{2}+2 \% \mathrm{O}_{2}$ increased the rate of internal browning disorder by $26 \%$. Therefore, CA storage can be used to maintain the quality of the apple if the optimal gas concentrations in the CA are applied to the storage strategy.
\end{abstract}

Key words : apple, quality, controlled atmosphere, storage, browning disorder

\section{서 론}

분류학상 장미과에 속하며 다년생 목본식물인 사과는 세계에서 가장 많이 소비되는 과실 중 하나로서 식이섬유, 당질, 무기질, 유기산, 폴리페놀 화합물 등을 다량함유하고

*Corresponding author. E-mail : hhchun@wikim.re.kr Phone : 82-62-610-1761, Fax : 82-62-610-1850

Received 10 June 2015; Revised 19 November 2015; Accepted 28 December 2015.

Copyright (c) The Korean Society of Food Preservation. All rights reserved.
있기 때문에 건강식품으로 인식되고 있고 관능적으로 맛이 우수하다 $(1,2)$. 국내에서는 사과의 주요 산지인 경북 영주, 안동, 청송, 의성, 충남 예산, 충북 충주 등에서 쓰가루, 홍로, 감홍, 후지 등 다양한 품종이 대량으로 재배되고 있다.

가을철인 10 월 말에서 11 월 초에 집중적으로 수확되는 만생종 사과는 당년에 약 $50 \%$ 가 소비되고, 나머지는 저온 저장되어 이듬해 6 월까지 대부분 유통되고 있다 $(3,4)$. 반면 조생종은 추석 출하에 맞춘 품종으로 저장력이 약한 단점이 있기 때문에 수확 직후 품질을 유지하는데 한계를 나타내며 저장 및 유통 중 손실이 발생되는 문제점이 있다. 따라서 사과의 수확시기 및 품종에 관계없이 연중 고품질의 사과를 
공급할 수 있는 경제적이고 효과적인 저장기술을 개발하여 사과 생산농가나 산지유통센터에 보급 및 활용할 수 있도록 하는 노력이 필요한 상황이다.

국내 사과의 수확 전 재배기술은 다른 선진국과 비교하 여 높은 수준에 있지만 수확 후 관리기술 측면에서는 미흡 하기 때문에 저장 중 숙성상태를 지나 노화가 진행되면서 세포 팽압의 감소, 과육 전분의 분해 및 세포벽 붕괴, 수분손 실 등 물리화학적 품질변화가 나타난다(2-4). 또한 저온 저 장고 내 온도관리가 설정한 값과 달리 $-1{ }^{\circ} \mathrm{C}$ 이하로 내려가는 등 불균일하게 유지되어 사과 조직의 결빙에 따른 동결 장해 피해가 발생하기도 한다(5,6). 따라서 수확 후 발생하 는 사과의 품질저하 및 부패, 장해발생 등 손실을 최소화하 고 품질이 불량한 상태로 유통되는 문제를 예방하기 위해서 는 수확 후 저장 일어나는 이화학적 품질 변화의 특성에 대한 이해와 함께 효과적인 수확 후 저장 기술이 적용되어 야 한다(7). 올바른 저장기술 확립은 시장 공급 과잉에 의한 가격 폭락을 방지하며 품질유지기한 증대로 내수 소비확대 는 몰론 원격지 수송 및 수출을 포함한 수요 확대도 가능하다. 수확 후 사과 품질 유지를 위한 저장 연구로 저온 저장, controlled atmosphere(CA) 저장과 modified atmosphere (MA) 포장 등이 수행되고 있으며(8-13), 이중 CA 저장기술 이 최근 농산업현장에서 다시 각광받고 있다. $\mathrm{CA}$ 저장은 저장고 내 $\mathrm{CO}_{2}, \mathrm{O}_{2}, \mathrm{~N}_{2}$ 등 기체 환경조성을 변화시켜줌으로 써 climacteric형인 사과의 호흡 급상승을 억제하여 저장성 을 향상시키는 기술로 우수한 효과가 국내외 연구진에 의해 입증되었다 $(2,14)$. 하지만 저장고 내 $\mathrm{O}_{2}$ 및 $\mathrm{CO}_{2}$ 농도가 사과 의 생리적 특성과 맞지 않을 경우 과육갈변, 조직의 수침 및 붕괴 등 생리적 장해가 발생한다(15-17). 국내에서도 1990년도 초반에 규모화 된 CA 저장시설이 사과저장 산업 에 도입된 후 갈변 등 저장장해 발생 등의 이유로 사업이 철수한 바 있지만 최근 사과 주산지에 위치한 산지유통센터 또는 대형 유통업체의 저장유통센터 등 몇 곳에서 제한적으 로 $\mathrm{CA}$ 저장시설이 운영되고 있다.

국외에서 'Empire', 'McIntosh', 'Braeburn', 'Royal Gala' 등 다양한 사과 품종별로 $\mathrm{CA}$ 저장 특성에 대한 연구가 이루어 졌다(2,11,16-18). 그러나 국내에서는 잠열재를 이 용한 이동식 저온 컨테이너 개발 연구, 지연 $\mathrm{CA}$ 저장이 저장 중 '후지' 사과의 품질에 미치는 영향 등 연구는 수행 되었지만 $\mathrm{CA}$ 환경제어가 가능한 저장시스템 개발하고 국 산 사과의 $\mathrm{CA}$ 저장기술 도입을 위한 최적 기체 환경조성 구명 연구는 미흡한 실정이다(19).

따라서 본 연구는 다양한 기체농도에서 $\mathrm{CA}$ 저장된 사과 의 품질분석을 통해 국산 사과의 저장성 향상을 도모하고, 경제적으로 국산 사과를 유통시키기 위한 기초자료를 제공 하는데 목적이 있다. 그러므로 본 연구에서는 기체치환 기 밀 챔버 및 저온 저장시스템을 개발하고 조생후지 사과의 $\mathrm{CA}$ 저장 중 $\mathrm{CO}_{2}$ 농도, $\mathrm{O}_{2}$ 농도와 습도변화에 따른 이화학적
품질 및 생리적 장해발생률을 분석하여 알아보고자 하였 다.

\section{재료 및 방법}

\section{실험재료}

본 실험에서 사용한 조생 '후지' 사과(Malus pumila)는 2014년 9월 중순에 경북 문경에 위치한 농가에서 수확한 제품으로 $250 \sim 300 \mathrm{~g}$ 의 크기가 균일한 사과 중 외관이 건전 하고 착색이 고른 사과를 선별하여 시료로 사용하였다.

\section{$\mathrm{CA}$ 저온 저장시스템 제작}

본 연구에서 개발한 $\mathrm{CA}$ 저온 저장시스템의 구조 및 제원 은 Fig. 1 에 나타냈다. 저온 저장시스템의 크기는 3,000 $\mathrm{mm}(\mathrm{L}) \times 1,500 \mathrm{~mm}(\mathrm{~W}) \times 1,500 \mathrm{~mm}(\mathrm{H})$ 와 저장고 내부에 기밀 챔버 10 개가 설치되도록 설계하였다. 챔버는 스테인리스 강판을 사용하여 $550 \mathrm{~mm}(\mathrm{~L}) \times 593 \mathrm{~mm}(\mathrm{~W}) \times 586 \mathrm{~mm}(\mathrm{H})$ 의 크기와 약 $190 \mathrm{~L}$ 의 내부용량으로 제작하였다. 챔버 앞면은 투명한 아크릴 판을 사용하였고 볼트로 압착하여 기밀을 유지할 수 있도록 하였으며 챔버 안에는 온도 습도, 이산화 탄소 및 산소 농도를 측정할 수 있는 정밀센서를 부착하였 다. Negative temperature coefficient(NTC) 방식의 온도 및 습도 센서(UE-H100, USEEM Instruments Inc., Suwon, Korea)의 정밀도는 각각 $\pm 0.15^{\circ} \mathrm{C}$ 와 $\pm 0.50 \% \mathrm{RH}$ 이다. 비분 산 적외선 방식의 이산화탄소 센서(IRSSX-E, SST Sensing Ltd., Scotland, UK)와 zirconium oxide 방식의 산소 센서 (O2S-FR-T2- 18BM-C-010V, SST Sensing Ltd., Scotland, $\mathrm{UK}$ )의 정밀도는 각각 $\pm 0.10 \%$ 와 $\pm 0.20 \%$ 이다. 저장시스템 외부에 설치한 순수 $\mathrm{CO}_{2}, \mathrm{O}_{2}$ 및 $\mathrm{N}_{2}$ 가스공급 장치와 가스혼 합기(MAP MIX 9001 ME, PBI Dansensor Co., Ringsted, Denmark)를 이용하여 챔버 별 설정한 CA 조건 농도로 혼합 하여 직경 $16 \mathrm{~mm}$ 에어호스와 에어펌프를 통해 혼합된 가스 를 주입시키고 각 챔버에 밸브를 설치하여 혼합된 가스의 주입량을 조절할 수 있도록 설계하였다. 챔버의 상부에 설 치된 환기팬을 작동시켜 주입된 가스를 순환시켰다. 또한 저장 중 발생하는 에틸렌을 흡착 제거를 위해 규조토 입자 에 충진된 $\mathrm{KMnO}_{4}$ 을 $20 \mathrm{~g}$ 을 반투막 필름에 넣고 각 챔버에 삽입시켰다. 챔버의 습도는 Fig. 2 와 같이 챔버 내 공기를 실리카겔(silica gel) 필터로 수분을 제거할 수 있는 장치를 제작하여 조절하였다. 습도제어 장치는 진공펌프, 습도센 서, 제습유닛과 바이패스 라인으로 구성되어 있다. 3 방향 솔레노이드 밸브는 진공펌프로부터 출력되는 공기의 습도 가 높을 때는 제습유닛의 실리카겔 필터로 통과하여 수분이 제거되고 설정된 습도에 도달하게 되면 공기가 실리카겔 필터를 통과하지 않고 바이패스 라인으로 우회하도록 장치 를 설계하였다. 
(a)

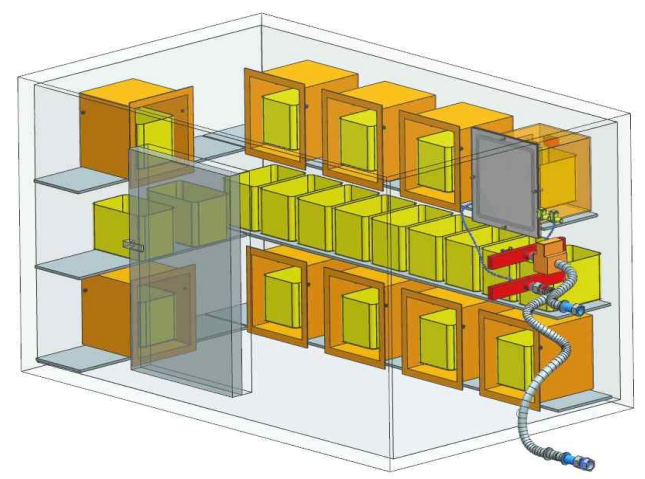

(c)

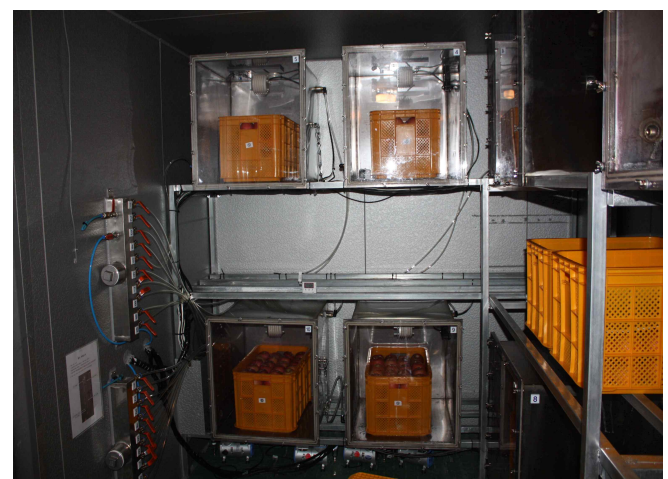

(b)

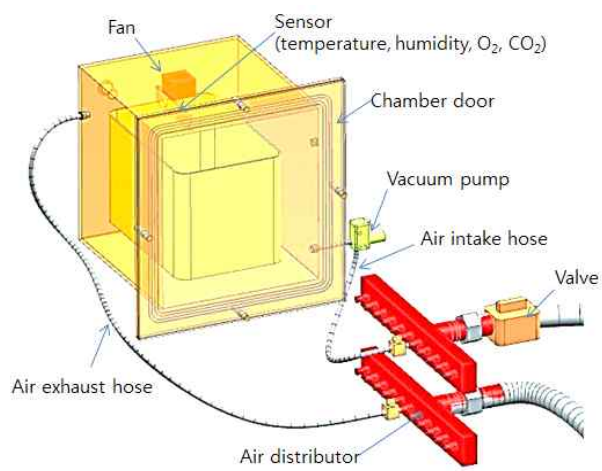

(d)

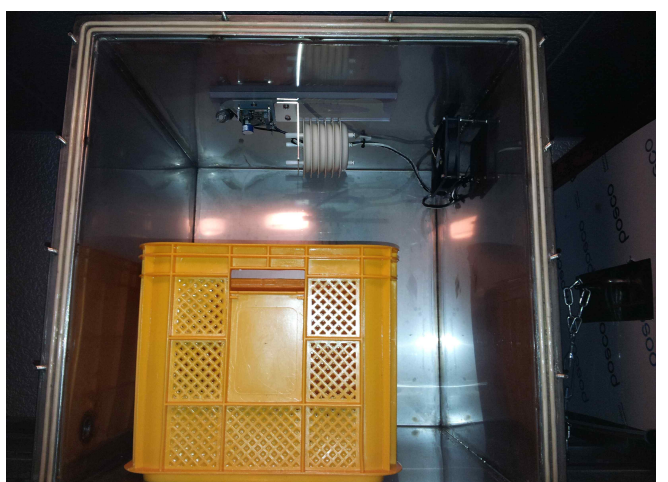

Fig. 1. Schematic views (a, b) and photos (c, d) of CA low temperature storage system (a, c) and gas control chamber (b, d).

\section{저장방법}

선별된 시료를 $\mathrm{HDPE}$ 박스 $(520 \times 360 \times 320 \mathrm{~mm})$ 에 옮긴 후 Table 1과 같은 저장방법 및 조건으로 실험을 실시하였 다. 챔버 1,2 와 3 의 $\mathrm{CA}$ 저장조건은 $1 \% \mathrm{CO}_{2}+2 \% \mathrm{O}_{2}$ 로 설정 하고 60,80 과 $95 \% \mathrm{RH}$ 로 각각 상대습도를 조절하였다. 챔버 4,5 와 6 은 $2 \% \mathrm{O}_{2}$ 와 $95 \% \mathrm{RH}$ 로 설정하고 $\mathrm{CO}_{2}$ 를 3 , 4 와 $5 \%$ 로 각각 농도를 조절하여 다른 $\mathrm{CA}$ 저장조건으로 모의하였다. 챔버 7 은 $1 \% \mathrm{CO}_{2}$ 와 $95 \% \mathrm{RH}$ 로 설정하고 $\mathrm{O}_{2}$ 를 $0.5 \%$ 로 조절하였으며 챔버 8 은 관행적인 저온 저장환경으 로 조성하여 대조구로 하였다.

Table 1. Storage conditions for early season Fuji apples

\begin{tabular}{ccccc}
\hline Chamber & $\begin{array}{c}\mathrm{CO}_{2} \text { concentration } \\
(\%)\end{array}$ & $\begin{array}{c}\mathrm{O}_{2} \text { concentration } \\
(\%)\end{array}$ & $\begin{array}{c}\text { Temperature } \\
\left({ }^{\circ} \mathrm{C}\right)\end{array}$ & $\begin{array}{c}\text { Relative } \\
\text { humidity }(\%)\end{array}$ \\
\hline 1 & $1 \pm 0.1$ & $2 \pm 0.2$ & $0 \pm 1$ & $95 \pm 5$ \\
2 & $1 \pm 0.1$ & $2 \pm 0.2$ & $0 \pm 1$ & $80 \pm 5$ \\
3 & $1 \pm 0.1$ & $2 \pm 0.2$ & $0 \pm 1$ & $60 \pm 5$ \\
4 & $3 \pm 0.1$ & $2 \pm 0.2$ & $0 \pm 1$ & $95 \pm 5$ \\
5 & $4 \pm 0.1$ & $2 \pm 0.2$ & $0 \pm 1$ & $95 \pm 5$ \\
6 & $5 \pm 0.1$ & $2 \pm 0.2$ & $0 \pm 1$ & $95 \pm 5$ \\
7 & $1 \pm 0.1$ & $0.5 \pm 0.2$ & $0 \pm 1$ & $95 \pm 5$ \\
$8^{1)}$ & $0.1 \pm 0.1$ & $21 \pm 0.2$ & $0 \pm 1$ & $95 \pm 5$ \\
\hline
\end{tabular}

${ }^{1)}$ Control.
사과의 이화학적 품질 측정

$\mathrm{CO}_{2}$ 와 $\mathrm{O}_{2}$ 농도 및 습도가 각기 다른 챔버에 저장된 조생 ‘후지' 사과의 70 일 저장 후 경도, 적정산도, 가용성고형물 함량, 중량감소율을 분석하였다. 사과 과육의 경도를 측정 하기 위해 texture analyzer(TA-XT2, Stable Micro System Ltd., Surrey, UK)를 사용하여 penetration test를 행하였다.

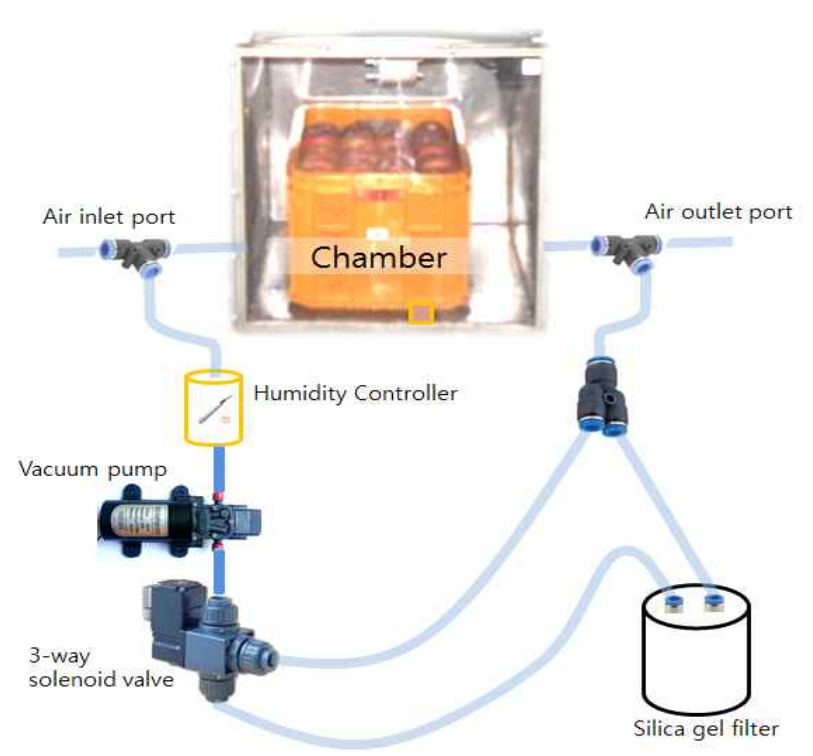

Fig. 2. Device used to control humidity in the chamber. 
지름 $5 \mathrm{~mm}$ puncture probe를 사용하였으며 test speed 2 $\mathrm{mm} / \mathrm{s}$ 속도와 $10 \mathrm{~mm}$ 깊이로 과육을 통과시킬 때 얻어지는 최대값을 측정하였다. 측정 횟수는 각 시료 당 10 개를 선발 하여 5 회 반복한 다음 평균값을 구하여 Newton(N)으로 나 타내었다. 적정산도를 측정하기 위해 시료 $20 \mathrm{~g}$ 과 증류수 $180 \mathrm{~mL}$ 를 혼합한 뒤 균질화 하였다. 균질된 시료 $20 \mathrm{~mL}$ 를 $0.1 \mathrm{~N} \mathrm{NaOH}$ (Daejung Chemical, Suwon, Korea) 용액으로 $\mathrm{pH}$ 8.2가 될 때 까지 적정하고 중화 적정에 소비된 0.1 $\mathrm{N} \mathrm{NaOH}$ 양 $(\mathrm{mL})$ 을 이용하여 사과의 주요 유기산인 malic acid 함량(\%)으로 계산하였다. 가용성 고형물 함량은 사과 과육을 착즙한 후 디지털 굴절당도계(RX-5000a, Atago Co., Tokyo, Japan)로 측정하여 ${ }^{\circ}$ Brix로 나타내었다. 사과 시료
의 저장 중 중량감소율은 시료의 초기중량을 측정한 후 저장기간 중 중량의 차이를 초기중량에 대한 백분율로 환산 하여 나타내었다.

\section{사과의 내부갈변 장해 발생률}

사과의 내부장해 발생률은 시료 50 개의 적도부를 횡단면 으로 절단하여 Fig. 3 과 같이 과육부분의 갈변이 발생된 시료를 전체 조사 시료에 대한 백분율로 나타내었다.

\section{통계처리}

모든 실험은 3 회 반복하여 측정하였으며 내부갈변 장해 발생률을 제외한 실험결과는 평균값 \pm 표준편차로 나타냈

(a)

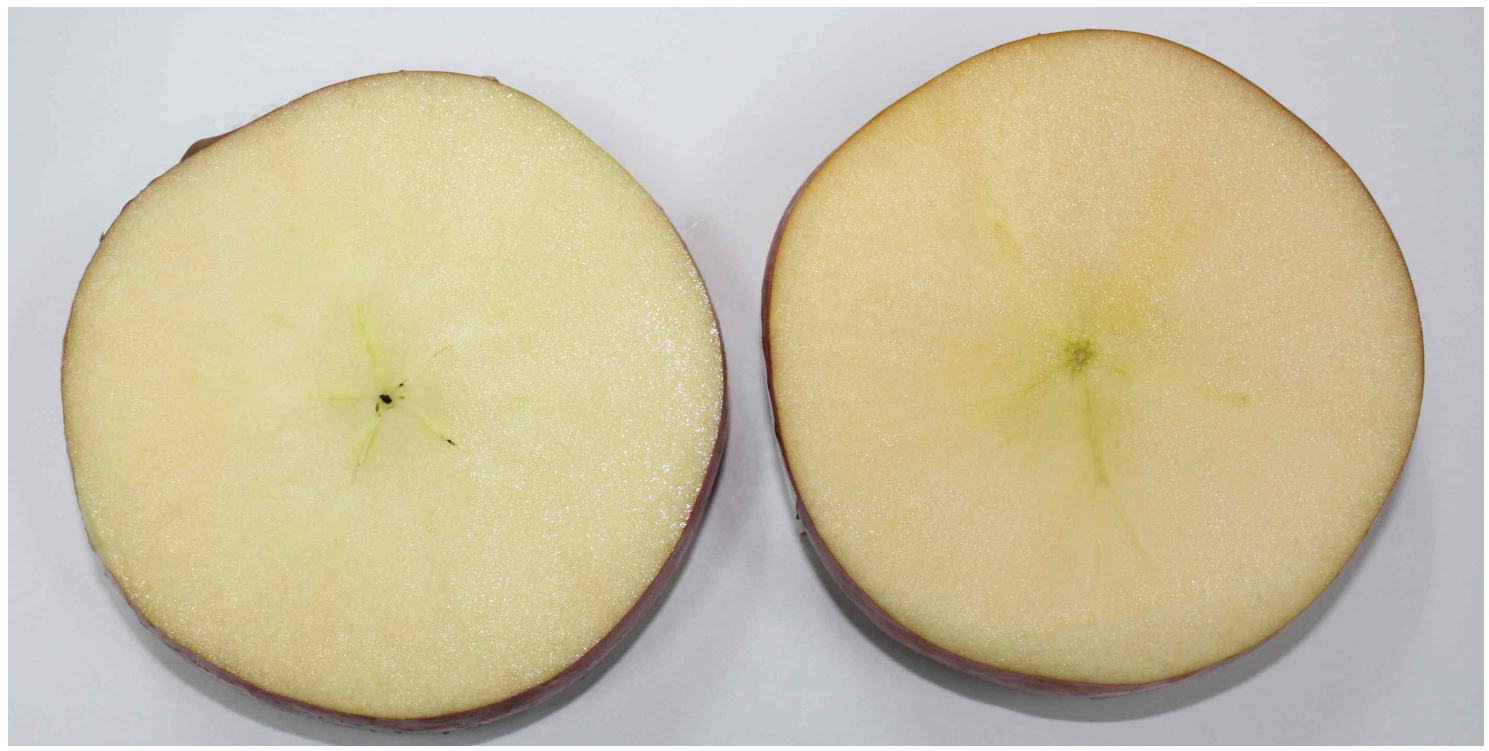

(b)

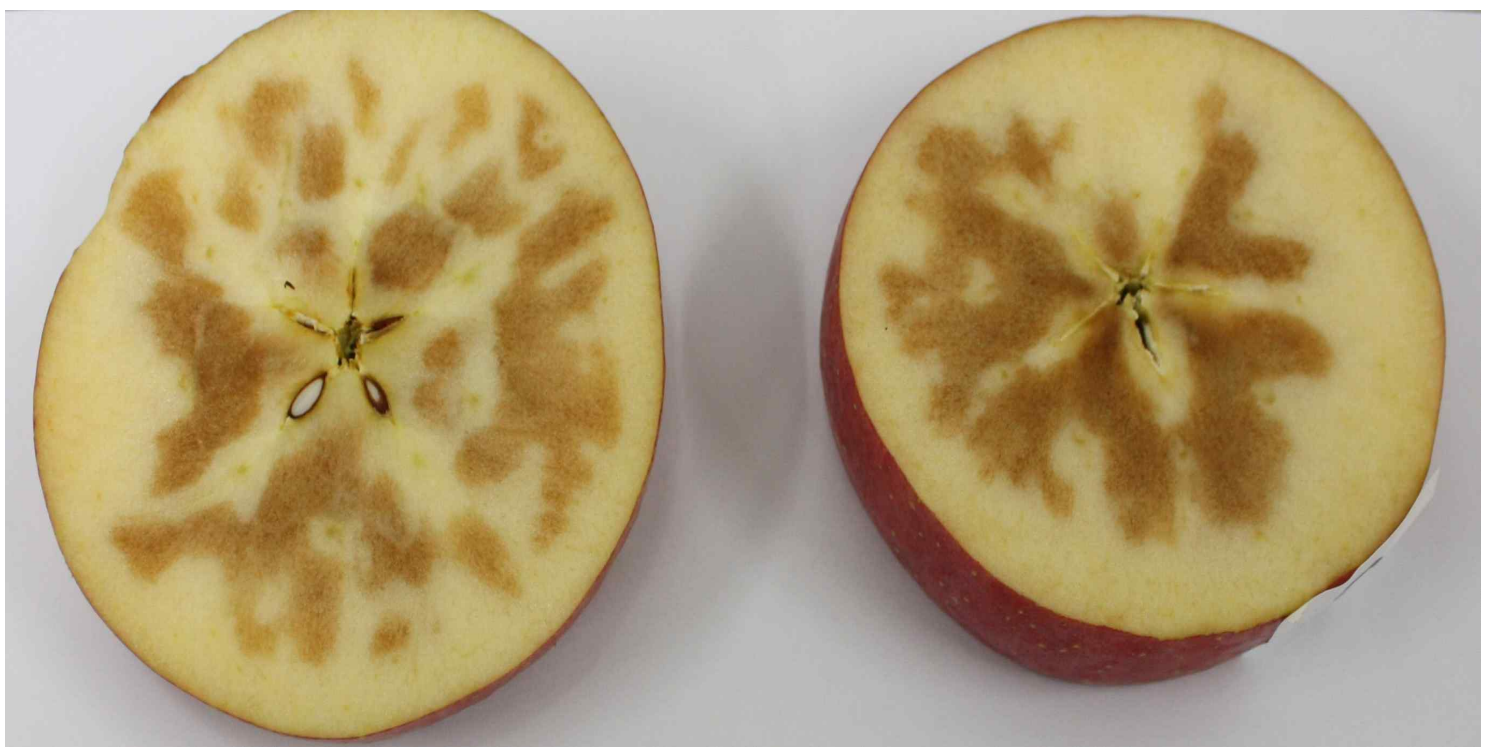

Fig. 3. Normal shape (a) and shape after internal browning (b) of early season Fuji apples stored under different CA conditions. 
다. 처리평균간의 유의성 검정은 SAS(Statistical Analysis System, 8.1, SAS Institute Inc., Cary, NC, USA) program을 이용하여 $\mathrm{p}<0.05$ 수준에서 Duncan's multiple range test 방법 을 사용하여 통계처리를 실시하였다.

\section{결과 및 고찰}

\section{저장 후 사과의 이화학적 품질 변화}

일반적으로 수확 후 사과는 저장 중 숙성과정에서 과육 의 전분이 당으로 가수분해, 가용성 고형물 함량 증가, 산 함량 감소, 과육의 연화 등 품질변화가 일어나며, 사과의 품질은 이화학적 품질인자들의 객관적인 수치로써 평가된 다 $(20,21)$.

$\mathrm{CA}$ 저온 저장시스템 안에 설치된 챔버 내 $\mathrm{CO}_{2}, \mathrm{O}_{2}$ 와 습도 등 저장환경 조건을 달리하여 70 일 동안 저장된 조생 ‘후지' 사과의 경도, 적정산도, 가용성고형물 함량, 및 중량 감소를 측정한 결과는 Table 2 와 같다.

Table 2. Change in physicochemical qualities of early season Fuji apples under different conditions after low temperature storage

\begin{tabular}{|c|c|c|c|c|}
\hline \multirow[b]{2}{*}{ Chamber } & \multicolumn{4}{|c|}{ Physicochemical parameters } \\
\hline & $\begin{array}{l}\text { Flesh firmness } \\
\text { (N) }\end{array}$ & $\begin{array}{c}\text { Titratable } \\
\text { acidity (\%) }\end{array}$ & $\begin{array}{c}\text { Total soluble } \\
\text { solid content } \\
\text { ( }{ }^{\circ} \text { Brix) }\end{array}$ & $\begin{array}{l}\text { Weight loss } \\
(\%)\end{array}$ \\
\hline Fresh sample ${ }^{1)}$ & $14.36 \pm 1.40^{a 3)}$ & $0.30 \pm 0.04 \mathrm{ab}$ & $12.67 \pm 0.95^{\mathrm{ab}}$ & $0 \pm 0 \mathrm{~d}$ \\
\hline 1 & $12.69 \pm 0.78^{\mathrm{bcd}}$ & $0.34 \pm 0.04^{\mathrm{a}}$ & $12.34 \pm 1.02^{\mathrm{b}}$ & $0.51 \pm 0.05^{\mathrm{c}}$ \\
\hline 2 & $13.00 \pm 1.44^{\text {abcd }}$ & $0.32 \pm 0.06^{\mathrm{ab}}$ & $13.49 \pm 0.98^{\mathrm{a}}$ & $0.59 \pm 0.14^{\mathrm{c}}$ \\
\hline 3 & $12.44 \pm 0.77^{\mathrm{cd}}$ & $0.33 \pm 0.03^{\mathrm{a}}$ & $13.12 \pm 0.71^{\mathrm{ab}}$ & $0.74 \pm 0.11^{\mathrm{b}}$ \\
\hline 4 & $13.23 \pm 0.70^{\mathrm{abc}}$ & $0.29 \pm 0.02^{\mathrm{b}}$ & $13.36 \pm 0.93^{\mathrm{ab}}$ & $0.53 \pm 0.10^{c}$ \\
\hline 5 & $13.53 \pm 1.02^{\mathrm{abc}}$ & $0.28 \pm 0.04^{b}$ & $12.50 \pm 0.76^{\mathrm{ab}}$ & $0.49 \pm 0.08^{\mathrm{c}}$ \\
\hline 6 & $14.21 \pm 1.27^{\mathrm{ab}}$ & $0.29 \pm 0.03^{b}$ & $12.82 \pm 0.62^{\mathrm{ab}}$ & $0.50 \pm 0.13^{\mathrm{c}}$ \\
\hline 7 & $12.77 \pm 1.17^{\mathrm{bcd}}$ & $0.34 \pm 0.06^{\mathrm{a}}$ & $13.44 \pm 0.68^{\mathrm{a}}$ & $0.53 \pm 0.11^{\mathrm{c}}$ \\
\hline $8^{2)}$ & $11.72 \pm 1.05^{\mathrm{d}}$ & $0.34 \pm 0.02^{\mathrm{a}}$ & $12.53 \pm 1.05^{\mathrm{ab}}$ & $1.02 \pm 0.10^{\mathrm{a}}$ \\
\hline
\end{tabular}

경도의 경우, 수확 후 시료로 사용한 사과는 $14.36 \mathrm{~N}$ 의 값을 나타냈다. 70 일 저장 후 대기조건으로 저장된 대조구 (챔버 8 )의 경도는 $11.72 \mathrm{~N}$ 의 값을 보인 반면 $1 \sim 5 \%$ $\mathrm{CO}_{2}+0.5 \sim 2 \% \mathrm{O}_{2}$ 농도로 기체치환 시킨 챔버 1 7에 저장된 사과시료는 12.44 13.93 N으로 대조구보다 높은 경도를 유지한 것으로 나타났다. Park 등(21)은 관행방법인 저온 저장과 비교하여 2 3\% 이산화탄소 및 산소 조건에서 CA 저장했을 시 '홍월' 사과의 경도가 높은 수준으로 유지되었 다고 보고하였다. 또한, Róth 등(22)은 6개월 동안 저온 저장
한 'Jonagold' 사과의 경도는 유의적으로 감소한 반면 CA 저장한 사과는 높은 경도를 유지하였다고 보고하였다. 저 온저장에 비해 높은 $\mathrm{CO}_{2}$ 와 낮은 $\mathrm{O}_{2}$ 조건으로 설정된 $\mathrm{CA}$ 저장환경에서 호흡에 의한 에틸렌 생성 감소와 pectinesterase, cellulase, polygalacturonase 등 세포벽분해효소 합성이 억제 됨에 따라 상대적으로 사과의 경도가 높게 유지된다(11).

저장 전 사과의 적정산도는 $0.30 \%$ 이었으며 70 일 저장 경과 후 챔버 1 8 처리구는 0.28 0.34\%로 처리구 간에 유의 적인 차이가 나타나지 않았다. 일반적으로 과실의 산도는 숙성이 일어나는 동안 호흡 중 기질이 소모되거나 당으로 전환되기 때문에 감소한다고 알려져 있지만 본 연구에서는 저장 중 조생 '후지' 사과의 산도 감소는 확인 할 수 없었다.

가용성고형물 함량은 사과의 품질을 판단하는 중요한 이화학적 품질 인자 중 하나로 성숙이 진행됨에 따라 전분 의 가수분해에 의해 당도가 증가하지만 수확 후에는 호흡기 질로 사용되어 감소하는 경향이 있다(24). 본 연구에서 다양 한 $\mathrm{CA}$ 환경으로 장기 저장된 '후지' 사과의 가용성고형물 함량은 $12.34 ~ 13.49{ }^{\circ} \mathrm{Brix}$ 수준으로 대부분 상 등급에 해당 하는 함량을 나타냈으며 챔버 1 8에 저장된 시료 간 유의적 인 차이를 보이지 않았다. 챔버 내 기체 환경변화는 저장 중 가용성 고형물 함량 변화에는 큰 영향을 미치지 않는 것으로 판단된다. 본 연구에서 가용성고형물 함량결과는 Lee 등(3)과 Park 등(23)이 보고한 국내에서 재배된 만생종 '후지' 사과의 가용성고형물 함량이 $14{ }^{\circ} \mathrm{Brix}$ 수준이라는 보고와 비교하여 차이를 나타냈다. 또한 '후지'의 가용성고 형물 함량은 만개 후 $163 \sim 169$ 일에 약 $12{ }^{\circ} \mathrm{Brix}$ 수준이었으 며 183 191일에 $14{ }^{\circ} \mathrm{Brix}$ 이상을 나타냈다고 보고하였다 (25). 따라서 '후지' 품종이 같아도 수확시기가 늦은 만생종 이 조생종보다 가용성고형물 함량이 높은 경향을 나타내는 것으로 판단된다.

사과 시료 70 일 저장 후 중량 감소를 측정한 결과, 대조구 는 $1.02 \%$ 의 감소율을 보여 $\mathrm{CA}$ 처리구보다 중량감소 폭이 가장 크게 나타났다. 특히, $\mathrm{CA}$ 저장조건인 챔버 4 7에서는 $0.49 \sim 0.53 \%$ 로 대조구와 비교하여 약 $0.5 \%$ 차이를 보였으며 95,80 과 $60 \% \mathrm{RH}$ 로 습도를 제어한 챔버 1,2 와 3 에서는 저장습도가 감소함에 따라 중량감소는 증가하는 경향을 나타냈다. 본 연구결과, 저장 후 조생 '후지' 사과 시료의 중량변화의 차이는 $\mathrm{CO}_{2}$ 와 $\mathrm{O}_{2}$ 농도조절에 의한 호흡작용 억제 및 상대습도에 기인하는 것으로 판단된다. 일반적으 로 사과는 약 $85 \%$ 이상 높은 수분을 함유하고 있어 수증기 에 의해 포화된 세포 간극내의 내부공기와 불포화된 외부공 기 사이의 수증기압 차이로 수분증발이 일어난다(26). 수확 후 저장 및 유통과정에서 습도가 낮을 경우 표피에서부터 수분이 증발되며 약 $5 \%$ 정도의 중량감소가 발생하면 위조 (wilting) 현상, 조직감 감소가 나타나 사과의 품질이 저하하 게 된다(26). 본 연구결과를 종합해 보면, 조생 '후지'사과의 $\mathrm{CA}$ 저장 시 당도 및 산도에 미치는 영향은 미미하였으나 
경도와 중량을 유지에 효과가 있는 것으로 나타났으므로 본 연구에서 제시한 저장 장해를 유발하지 않는 습도, $\mathrm{CO}_{2}$ 와 $\mathrm{O}_{2}$ 농도 등의 $\mathrm{CA}$ 조건을 활용한다면 $\mathrm{CA}$ 저장이 관행적 인 저온저장에 비해 사과의 품질유지와 중량감소 억제가 가능할 것으로 사료된다.

\section{저장 후 사과의 내부갈변 장해 발생률}

$\mathrm{CA}$ 저장장해는 저장 중 $\mathrm{CO}_{2}$ 와 $\mathrm{O}_{2}$ 등 기체 환경조성이 과실의 생리적 특성과 맞지 않을 경우 발생하며, 저 산소 장해, 고 이산화탄소 장해와 두 요인에 의한 복합장해 등이 있다(17,27). 저장 후 조생“ 후지' 사과 시료의 과육에 갈변 발생률을 조사한 결과, 대조구(챔버 8 )에서는 $2 \%$ 의 발생률 을 보인 반면 $1 \% \mathrm{CO}_{2}+2 \% \mathrm{O}_{2}$ 조건으로 설정된 챔버 1 3에 서는 4 6\%의 발생률을 나타냈다(Table 3). 특히, $\mathrm{CO}_{2}$ 농도 를 3 5\%로 설정된 챔버 4 6의 사과 시료에서는 20 26\% 높은 갈변 발생률을 보여, 본 연구에서는 고농도 $\mathrm{CO}_{2}$ 가 저장 중 사과 과육의 내부 갈변 발생에 영향을 미치는 것으 로 판단되었다. $4 \%$ 이상의 고농도 $\mathrm{CO}_{2}$ 에 노출될 경우 succinic oxidase의 활성이 억제되어 조직 내 succinic acid가 축적됨으로써 사과의 중심 부위의 갈변이 발생하며 품종에 따라 유관속을 따라 형성되거나 임의로 흩어진 모양으로 발달한다고 보고하였다(28). 한편, 과육에 수침현상이 있는 조직에서 sorbitol이 fructose로 전환하는 능력이 상실되며 심한 경우 ethanol 및 acetaldehyde가 축적, 조직 내 혐기성 상태를 형성하며 내부갈변 또는 조직붕괴 현상이 발생한다 고 보고하였다(11,29). Wang 등(30)은 'Empire' 사과를 $3^{\circ} \mathrm{C}$ 에서 대기조건 또는 $0 \% \mathrm{CO}_{2}+1.5 \% \mathrm{O}_{2}$ 조건으로 30 일 간 저장 시 장해발생은 일어나지 않았지만 저장고 내 $3 \%$ 와 $5 \% \mathrm{CO}_{2}$ 농도 조건에서는 사과 시료에 심각한 장해가 발생 했다고 보고하였는데 $\mathrm{CO}_{2}$ 농도가 $3 \%$ 이상에서 갈변장해가 증가하였다는 점이 본 연구결과와 유사하다.

Chung 등(31)은 '홍로' 사과의 경우 $3 \% \mathrm{CO}_{2}+1 \% \mathrm{O}_{2} \mathrm{CA}$ 조건으로 $1^{\circ} \mathrm{C}$ 에서 약 50 일 간 저장하였을 때 $\mathrm{CO}_{2}$ 장해로 인한 내부갈변 등 부패과는 발생하지 않았다고 보고하였

Table 3. Internal browning disorder (\%) of early season Fuji apples under different conditions after low temperature storage

\begin{tabular}{cc}
\hline Chamber & Internal browning disorder $(\%)^{2)}$ \\
\hline 1 & 4 \\
2 & 6 \\
3 & 4 \\
4 & 20 \\
5 & 26 \\
6 & 24 \\
7 & 10 \\
$8^{1)}$ & 2 \\
\hline${ }^{1)}$ Control. \\
of samples $\times 100$.
\end{tabular}

다. Jung과 Watkins(17)은 'Empire' 사과를 $2 \% \mathrm{CO}_{2}+3 \% \mathrm{O}_{2}$ 의 단일 $\mathrm{CA}$ 환경으로 설정한 챔버에서 10 개월간 저장했을 때 저장 6개월 이후 내부갈변 발생이 급격히 증가하였으며 수확 후 1-MCP 처리한 사과에서 갈변율이 높았다고 보고 하였다. 또한 농산물의 저장 중 발생하는 생리적 장해의 발생 정도는 수확 시 성숙도에 따라 큰 차이가 있으며 고이 산화탄소 또는 저산소 장해는 미세한 기체농도 차이, 부적 합한 온도와 습도 등 환경에 노출된 기간에 따라 크게 달라 질 수 있다 $(32,33)$. 이러한 결과와 본 연구를 통해서 수확 후 사과의 $\mathrm{CA}$ 저장기술 활용 시 최적 $\mathrm{CO}_{2}$ 와 $\mathrm{O}_{2}$ 의 농도가 사과 품종과 수확시기에 따라 다르게 적용되어야 할 것이 다. 특히, 저장고 내 $\mathrm{CO}_{2}$ 농도에 민감한 조생 '후지' 사과의 경우, 본 연구를 통해 저온저장 또는 $\mathrm{CA}$ 저장 시 $\mathrm{CO}_{2}$ 농도를 $2 \%$ 를 초과하지 않도록 저장고 내부의 기체 환경 관리의 필요성을 제시할 수 있다. 또한 장기 저장 후 유통하는 수확 후 관리 프로그램에서는 $\mathrm{CA}$ 저장 기술 적용 시 사과의 장해 발생을 억제 및 예측 할 수 있어야만 $\mathrm{CA}$ 기술 적용이 확대 될 것이다. 사과의 저장 중 발생하는 생리적 장해는 재배지역 기후, 과수원의 영양상태, 수분관리, 수확시기 등 수확 전 요인에 따라 발생률이 차이가 있지만 저장환경에 큰 영향을 받기 때문에 본 연구결과가 국산 사과의 저장환 경에 따른 품질변화와 장해발생을 예방을 위한 기초자료로 활용될 것으로 기대한다.

\section{요 약}

본 연구는 $\mathrm{CA}$ 저장시스템 및 기체치환 기밀 챔버를 개발 하여 조생 '후지' 사과의 저온저장 중 기체 환경 조성에 따른 이화학적 품질변화 및 내부갈변 장해 발생률 구명에 따른 국산 사과의 $\mathrm{CA}$ 저장기술 확립을 위한 기초 자료를 얻고자 수행되었다. 70 일 저장 후 경도는 $\mathrm{CA}$ 조건 챔버에 저장된 사과 시료가 대조구와 비교하여 유의적으로 높은 값을 보였다. 중량감소율은 1 5\% $\mathrm{CO}_{2}+0.5 ~ 2 \% \mathrm{O}_{2} \mathrm{CA}$ 조건 및 $95 \% \mathrm{RH}$ 습도로 설정된 챔버의 시료가 0.49 0.53\%을 나타내어 대조구의 $1.02 \%$ 보다 낮은 감소율을 보였다. 한편, 적정산도와 가용성고형물 함량은 챔버 1 8에 저장된 사과 시료 간에 유의적인 차이를 나타내지 않았다. 내부장해 발 생은 일반 저온저장한 대조구(챔버 8 )가 $2 \%$ 를 나타냈으며 $1 \% \mathrm{CO}_{2}+2 \% \mathrm{O}_{2} \mathrm{CA}$ 조건(챔버 1)에서는 약 $4 \%$ 의 내부 갈변 장해율을 나타내었다. 한편, $3 ~ 5 \% \mathrm{CO}_{2}+2 \% \mathrm{O}_{2} \mathrm{CA}$ 조건(챔 버 4 6)에서는 20 26\%의 높은 내부갈변 장해발생률을 보 였기 때문에 조생 '후지' 사과의 경우 $\mathrm{CA}$ 저장 시 $\mathrm{CO}_{2}$ 농도를 $2 \%$ 미만으로 유지해야하는 것으로 나타났다. 본 연구결과 $1 \% \mathrm{CO}_{2}+2 \% \mathrm{O}_{2} \mathrm{CA}$ 조건 및 $95 \% \mathrm{RH}+0^{\circ} \mathrm{C}$ 저장환 경에서 사과의 호흡억제 및 숙성·노화지연 등으로 계획된 기간 동안 품질유지가 가능할 것으로 판단된다. 향후 다양 
한 품종의 국산 사과의 $\mathrm{CA}$ 저장기술 실용화를 위해 재배지 역 및 수확시기 등에 따른 이화학적 및 관능적 품질 분석과 소비자 기호도 조사의 데이터베이스화하여 $\mathrm{CA}$ 저장 장해 극복 방안 연구가 이루어져야 할 것으로 여겨진다.

\section{감사의 글}

본 연구는 2015년 농촌진흥청 기관고유사업(과제번호: PJ010011)의 지원에 의해 이루어진 것으로 감사드립니다.

\section{References}

1. Hoang NTT, Golding JB, Wilkes MA (2011) The effect of postharvest 1-MCP treatment and storage atmosphere on 'Cripps Pink' apple phenolics and antioxidant activity. Food Chem, 127, 1249-1256

2. Both V, Brackmann A, Thewes FR, Ferreira DdeF, Wagner R (2014) Effect of storage under extremely low oxygen on the volatile composition of 'Royal Gala' apples. Food Chem, 156, 50-57

3. Lee JW, Kim SH, Hong SI, Jeong MC, Park HW, Kim DM (2003) Internal and external quality of Fuji apples. Korean J Food Preserv, 10, 47-53

4. Park HW, Ryu NH (2013) Freshness of 'Fuji' apples packed MA film treated with acid and anti-fogging agents. Korean J Packaging Sci Technol, 19, 43-50

5. Zhu Z, Liu R, Li B, Tian S (2013) Characterisation of genes encoding key enzymes involved in sugar metabolism of apple fruit in controlled atmosphere storage. Food Chem, 141, 3323-3328

6. Lim BS, Oh SY, Lee JW, Hwang YS (2007) Influence of 1-methylcyclopropene treatment time on the fruit quality in the 'Fuji' apple (Malus domestica). Korean J Hort Sci Technol, 25, 191-195

7. Cao J, Zhang H, Yang Q, Ren R (2013) Efficacy of Pichia caribbica in controlling blue mold rot and patulin degradation in apples. Int J Food Microbiol, 162, 167-173

8. Costa F, Cappellin L, Fontanari M, Longhi S, Guerra W, Magnago P, Gasperi F, Biasioli F (2012) Texture dynamics during postharvest cold storage ripening in apple (Malus $\times$ domestica Borkh.). Postharvest Biol Technol, 69, 54-63

9. Toivonen PMA, Hampson CR (2014) Relationship of IAD index to internal quality attributes of apples treated with 1-methylcyclopropene and stored in air or controlled atmospheres. Postharvest Biol Technol, 91, 90-95

10. Janisiewicz WJ, Saftner RA, Conway WS, Yoder KS (2008) Control of blue mold decay of apple during commercial controlled atmosphere storage with yeast antagonists and sodium bicarbonate. Postharvest Biol Technol, 49, 374-378

11. Gwanpua SG, Verlinden BE, Hertog MLATM, Bulens I, Van de Poel B, Van Impe J, Nicolaï BM, Geeraerd $\mathrm{AH}$ (2012) Kinetic modeling of firmness breakdown in 'Braeburn' apples stored under different controlled atmosphere conditions. Postharvest Biol Technol, 67, 68-74

12. Kweon HJ, Choi DG, Lee JW, Jung HY, Choung MG, Kang IK (2013) Effects of delayed CA treatment on fruit quality of 'Fuji' apples during storage. Protected Hort Plant Fac, 22, 202-208

13. Saftner RA, Abbort JA, Conway WS, Barden CL, Vinyard BT (2002) Instrumental and sensory quality characteristics of 'Gala' apples in response to prestorage heat, controlled atmosphere, and air storage. J Amer Soc Hort Sci, 127, 1006-1012

14. Park YM, Park HG, Lim BS (2011) Analysis of postharvest 1-MCP treatment and CA storage effects on quality changes of 'Fuji' apples during export simulation. Korean J Hort Sci Technol, 29, 224-231

15. Lumpkin C, Fellman JK, Rudell DR, Mattheis JP (2015) 'Fuji' apple (Malus domestica Borkh.) volatile production during high $\mathrm{pCO}_{2}$ controlled atmosphere storage. Postharvest Biol Technol, 100, 234-243

16. Volz RK, Biasi WV, Grant JA, Mitcham EJ (1998) Prediction of controlled atmosphere-induced flesh browning in 'Fuji' apple. Postharvest Biol Technol, 13, 97-107

17. Jung SK, Watkins CB (2011) Involvement of ethylene in browning development of controlled atmospherestored 'Empire' apple fruit. Postharvest Biol Technol, 59, 219-226

18. Watkins CB, Nock JF (2012) Rapid 1-methylcyclopropane (1-MCP) treatment and delayed controlled atmosphere storage of apples. Postharvest Biol Technol, 69, 24-31

19. Kweon KH, Kim JH, Jeong JW (2008) Characteristics maintenance internal temperature of apple and portable low-temperature container by using phase change materials. Korean J Food Preserv, 15, 15-20

20. Watkins CB, Nock JF, Whitaker BD (2000) Responses of early, mid and late season apple cultivars to postharvest application of 1-methylcyclopropene (1-MCP) under air 
and controlled atmosphere storage conditions. Postharvest Biol Technol, 19, 17-32

21. Park YM, Yoon TM, Hwang MG (2005) Analysis of storage method and marketing temperature effects on the storage potential of mid-season apple cultivar 'Hongwol'. Korean J Hort Sci Technol, 23, 49-55

22. Róth E, Berna A, Beullens K, Yarramraju S, Lammertyn J, Schenk A, Nicolaï B (2007) Postharvest quality of integrated and organically produced apple fruit. Postharvest Biol Technol, 45, 11-19

23. Park YM, Choi JS (2001) Instrumental and sensory analysis of fruit quality in relation to storability of 'Fuji' apples. Food Sci Biotechnol, 10, 488-492

24. Yoo J, Kim DH, Lee J, Choi DG, Han JS, Kwon SI, Kweon HJ, Kang IK (2013) Effect of preharvest sprayable 1-methylcyclopropene (1-MCP) treatment on fruit quality attributes in cold stored 'Gamhong' apples. Protected Hort Plant Fac, 22, 279-283

25. Sagong DH, Kweon HJ, Song YY, Park MY, Kang SB, Yoon TM (2013) Fruit quality and storability by harvest time at 'Fuji'/M.9 apple orchard located in the area with a high air temperature during the fall season. Korean J Hort Sci Technol, 31, 437-446

26. Koh HY, Park MH, Shin DH, Min BY (1984) Prediction of weigh losses and quality changes in long storage of apples. J Korean Agr Chem Soc, 27, 146-150

27. Burmeister DM, Dilley DR (1995) A 'scald-like' controlled atmosphere storage disorder of Empire apples-a chilling injury induced by $\mathrm{CO}_{2}$. Postharvest Biol Technol, 6, 1-7

28. Lee J, Mattheis JP, Rudell DR (2012) Antioxidant treatment alters metabolism associated with internal browning in 'Braeburn' apples during controlled atmosphere storage. Postharvest Biol Technol, 68, 32-42

29. Argenta L, Fan X, Mattheis J (2000) Delaying establishment of controlled atmosphere or $\mathrm{CO}_{2}$ exposure reduces 'Fuji' apple $\mathrm{CO}_{2}$ injury without excessive fruit quality loss. Postharvest Biol Technol, 20, 221-229

30. Wang Z, Kosittrakun M, Dilley DR (2000) Temperature and atmosphere regimens to control a $\mathrm{CO}_{2}$-linked disorder of 'Empire' apples. Postharvest Biol Technol, 18, 183-189

31. Chung DS, Hong YP, Lee Y (2006) Effects of modified atmosphere film packaging application and controlled atmosphere storage on changes of quality characteristics in 'Hongro' and 'Gamhong' apples. Korean J Hort Sci Technol, 24, 48-55

32. Park YM, Kim HS, Kim TW, Kim TH, Park YJ (2015) Optimized controlled atmosphere regimen for storage for fresh fischer's ligularia (Ligularia fischeri Turcz.) leaves. Korean J Hort Sci Technol, 33, 375-382

33. Watkins CB (2000) Responses of horticultural commodities to high carbon dioxide as related to modified atmosphere packaging. HortTechnology, 10, 501-506 